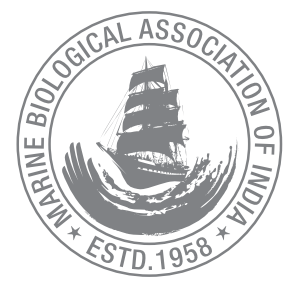

\title{
Physicochemical characteristics and benthic faunal constituents of a few seagrass and mangrove habitats of Tuticorin coast, Gulf of Mannar
}

\author{
P. S. Asha ${ }^{1 *}$, K. Diwakar' ${ }^{2}$ H. Sivanesh ${ }^{1}$, K. G. Mini ${ }^{3}$ and V. Kripa ${ }^{3}$ \\ 'Regional Station of ICAR- CMFRI, Tuticorin-628 001, Tamil Nadu, India. \\ 2Regional Station of ICAR-CMFRI, CIBA Campus, Chennai-600 028, Tamil Nadu, India. \\ ${ }^{3}$ ICAR-Central Marine Fisheries Research Institute, Kochi-628018, Kerala, India. \\ *Correspondence e-mail:ashasanil@gmail.com
}

Received: 30 Nov 2019 Accepted: 20 Nov 2020 Published: 25 Nov 2020

Original Article

\begin{abstract}
Rapid industrialisation and coastal developmental activities have caused considerable damages to the coastal habitats and their associated fauna and flora of Tuticorin coast. The status of the physicochemical and biological aspects indicating the healthiness of selected seagrass and mangrove habitats of Tuticorin coast was studied during 2013-15. The water and sediment quality parameters and the benthic in-faunal constituents were assessed monthly adopting the standard procedures. Our study indicated that the mangrove habitat was profoundly impacted due to the influence of high saline effluents from neighbouring salt pans. The mean values of most of the water quality parameters like salinity $(37.87 \pm 1.86 \mathrm{ppt})$; chlorophyll-a $\left(8.2 \pm 2.95 \mathrm{mg} \cdot \mathrm{m}^{-3}\right) ; \quad$ TSS $\quad\left(529.6 \pm 47.13 \mathrm{mg} \cdot \mathrm{L}^{-1}\right)$ ammonia $\left(0.12 \pm 0.02 \mu \mathrm{g} . \mathrm{L}^{-1}\right)$; nitrite $\left(1.96 \pm 0.92 \mu \mathrm{g} \mathrm{L}^{\mathrm{L}^{-1}}\right)$; phosphate $\left(8.67 \pm 2.58 \mu \mathrm{g} . \mathrm{L}^{-1}\right)$ were reported abnormal from the mangrove habitats. The seagrass habitat was impacted mainly by the activities of the neighbouring port, causing comparatively higher total suspended solids and dissolved solids in the water. Parameters like, $\mathrm{DO}$, salinity, chlorophyll, $\mathrm{TSS}_{1} \mathrm{NH}_{3^{\prime}} \mathrm{NO}_{2^{\prime}} \mathrm{SiO}_{3}$ in seawater and coarse and fine sand proportions of sediments were significantly varied between habitats $(p<0.05)$. The lower density and less diverse in-faunal constituents also proved the harshness of the sediments of both the habitats. The study also warrants the need for effective
\end{abstract}

management strategies for conservation and the sustainable utilisation of these resources.

Keywords: Seagrass, mangrove, habitats, water and sediment quality, infaunal constituents

\section{Introduction}

Seagrass and mangrove habitats represent a highly dynamic, productive and fragile ecosystem of the world and are well known for its high primary and secondary productivity, ability to stabilize the sediments, production of a vast quantity of detritus, trace metals and support of diverse floral and faunal communities. They offer food and shelter to a large population of juvenile and adult fishes and also provide both habitat and protection to the sediment-dwelling in-faunal organisms living within the substratum.

The distribution and growth of seagrasses are regulated by a variety of water quality parameters such as temperature, salinity, nutrient availability, substratum characteristics, turbidity and submarine irradiance (Abal and Dennison, 1996; Dennison and Kirkman, 1996). The most significant variables which influence 
the mangrove species composition, distribution, and zonation are temperature, salinity, tides, rainfall, light and wind (Srilatha et al., 2013). Worldwide the decline of these submerged macrophyte populations have been attributed to an increase in water column turbidity, dissolved nutrients and consequent epiphyte accumulation (Moore et al., 1996).

Anthropogenic pressure of various sources and magnitude such as aquaculture, pollution, boating, construction, dredging and landfill activities, and destructive fishing practices bring about many changes in the physicochemical characteristics, which affect the biotic elements of these habitats. Because of their sensitivity to changes in water and sediment qualities, these habitats have been recognized as important indicator species that reflect the overall health of coastal ecosystems (Prabhakaran et al., 2013). Similarly the in-faunal constituent could play an essential role in the food web and generally reflect the health of these habitats and are used as effective tools in biomonitoring programmes (Anilakumari, 2016). Similarly, Boye et al. (2017) postulate a substantial spatio-temporal variability of all components of epifaunal and infaunal diversity, along with site-specific dynamics of these habitats.

Because of the rapid industrialisation and coastal development, the degradation of the coastal habitats and their associated fauna and flora is a common phenomenon in Tuticorin coast. The status of the physicochemical and biological aspects indicating the healthiness of seagrass and mangrove habitats are absent from this region; hence the present work was conducted to elucidate the present status, to prioritize the management measures for conservation and sustainable utilization of these resources.

\section{Material and methods}

The present work was done for three years during 2013-15 and samples for seawater, and sediment quality parameters were collected from seagrass and mangrove habitats on a monthly basis. The seagrass bed opposite to the Tuticorin Port Trust administrative blocks which are under the threat of port reclamation activities was fixed as St.1,(Lat.08 $044^{\prime} 986^{\prime \prime} \mathrm{N}$; Long. $\left.078^{\circ} 011^{\prime} 566^{\prime \prime} \mathrm{E}\right)$ and Mangrove beds nearer to Karapad lagoon (Lat.08 $046^{\prime} 374^{\prime \prime} \mathrm{N}$; Long.078 $009^{\prime} 477^{\prime \prime}$ E) which are impacted by the discharges from nearby salt pans was fixed as St.2.

13 physicochemical parameters of seawater like dissolved oxygen, pH, salinity, chlorophyll, GPP, NPP, ammonia, T.S.S, T.D.S, and nutrients like $\mathrm{NO}_{2}, \mathrm{NO}_{3}, \mathrm{PO}_{4}, \mathrm{SiO}_{3}$ were analysed following the standard procedures. The data were pooled to four different seasons of three months each like summer (April, May and June); pre-monsoon (July, August, and September); monsoon (October, November, and December) and post- monsoon (January, February and March) for the convenience of interpretation. In situ measurement of air and water temperatures were made using a high precision thermometer. Salinity was determined by Mohr's titration method (Grasshoff, 1983). Ammonia was estimated by phenol hypochlorite method (Solarzano, 1969) and the nutrients were determined using Spectrophotometer (Genesis 10 model) as per the procedure of Grasshoff et al. (1999). Primary production was estimated by dark and light bottle method, and Winkler's method was employed for the estimation of oxygen (Winkler, 1888), and the same was converted into carbon equivalent using a PQ of 1.25 for obtaining the gross production. Chlorophyll-a was estimated and calculated, according to Parsons et al. (1984).

Core sampler of $20 \mathrm{~cm}$ long and $3 \mathrm{~cm}$ diameter of lumen was used to collect subsurface sediment samples from the above-said locations during low tide time. The samples were dried, pulverized and sieved for the estimation of sediment quality parameters. The texture of sediment was analysed by following the pipette methods (Lewis, 1984). The organic carbon, organic matter and nitrogen of the sediments were estimated by Walkley-Black (1934) method. For seagrass biomass estimation, a quadrate $\left(0.0625 \mathrm{~m}^{-2}\right)$ was placed at random in triplicates, and all the above ground seagrass materials found in the quadrate were collected and washed thoroughly with the seawater to remove debris. Moisture from the samples was removed using adsorbent paper and weighed to get the above-ground biomass. The mean of three quadrate samplings was considered for computing the seagrass biomass per square meter, and the mean values were expressed in terms of gram fresh weight per square meter (g.fr.wt. $\mathrm{m}^{-2}$ ). Separate benthos samples for in-faunal constituents were also collected from a quadrate $\left(0.0625 \mathrm{~m}^{-2}\right)$ in triplicates from these two habitats during the period 2014-15. The isolation and extraction of the in-faunal benthic organisms were carried out by flotation decantation method (Holme and Intyre, 1971). The decanted samples were differentially sieved through $500 \mu \mathrm{m}$ and $42 \mu \mathrm{m}$ mesh size and later preserved in $5 \%$ buffered formaldehyde with $1 \%$ Rose Bengal as stain before sorting and enumeration of species composition and biomass. The mean values of all the parameters were used for statistical interpretation of the results. The one-way analysis of variance ANOVA and correlation between all possible combinations were tested. Tukey's pair wise comparison tests were performed to test the significant seasonal differences between parameters. The statistical analysis was performed using SPSS software (version 20; Chicago, USA). The Principal Component Analysis was applied to the data set of physico-chemical variables to extract the primary factors and mechanisms that control both the habitats. FactoMine $R$ (Sebastien Le et al., 2008) and factoextra (Alboukadel and Mundt, 2017) packages in $R$ computing environment ( $R$ Core Team, 2019) were used to perform principal component analysis. 


\section{Results and discussion}

\section{Physicochemical characteristics}

The annual variation in the physicochemical parameters of the seagrass and mangrove habitats are depicted in Table 1. In the mangrove habitat, the air temperature (AT) ranged between $25^{\circ} \mathrm{C}$ and $38.2^{\circ} \mathrm{C}$ with the highest mean of $34.4 \pm 2.39^{\circ} \mathrm{C}$ during 2014 . The air temperature was comparatively lower in the seagrass habitat and varied from 25.5 to $36^{\circ} \mathrm{C}$ with the highest mean of $33.7 \pm 1.2^{\circ} \mathrm{C}$ during the pre-monsoon period of 2014 . The sea surface temperature (SST) ranged between 25.5 and $39.5^{\circ} \mathrm{C}$ and 26 and $33.5^{\circ} \mathrm{C}$ for mangrove and seagrass habitats, respectively. The mean value was highest of $32.5 \pm 3.5^{\circ} \mathrm{C}$ for the mangrove habitat. Strong positive correlations were noticed between AT and SST $(p<0.01)$. The annual and seasonal variations were also significantly different between the two habitats $(p<0.05)$. The atmospheric temperature significantly differed between post monsoon and summer; post-monsoon and pre-monsoon and between summer and monsoon $(p<0.01)$. However, the sea surface temperature was significantly varied between post-monsoon and summer only $(p<0.01)$. The mean values of both air temperature and water temperatures recorded in the present study was more or less similar to the observation made by Sulochanan et al. (2011) in Gulf of Mannar and Sridhar et al. (2008) in Palk Bay. There was a wide fluctuation in the air as well as water temperatures noticed between the two habitats. Kathiresan (2000) has reported such temporal fluctuations in temperature correlating to the summer and winter variations in Pichavaram mangroves and which may be due to the increased solar radiation and heavy precipitation as indicated by Kannan and Kannan (1996).

Wide variation in salinity was noticed in the mangrove habitat due to the intrusion of saltwater effluent from neighbouring saltpans. In the mangrove habitat, the salinity varied between 13.7 and $55.17 \mathrm{ppt}$ with the highest mean of $37.87 \pm 1.86 \mathrm{ppt}$. whereas in the seagrass habitats, it was between 19.3 to $39.9 \mathrm{ppt}$ with the highest mean of $32.8 \pm 1.43 \mathrm{ppt}$. A significant difference was noticed in the variation in salinity between seagrass and mangrove habitats $(p<0.05)$. The freshwater influx of northeast monsoon has caused the reduction in salinity at both stations. The influence of freshwater influx in lowering the coastal water salinity was already reported (Asha et al., 2007; Kamalkanth et al., 2012). The salinity indicated in the seagrass habitat is more or less similar to the observation made by Sridhar et al. (2008) in Palk Bay. In the present study, extreme variation in salinity in mangrove habitats has been noticed, which might be due to the influence of high saline effluent from the adjacent salt pans. Such a phenomenon of high salinity fluctuations in mangrove ecosystems due to the salt pans effluent has already been reported (Tewari et al., 2003; Jayanthi et al., 2010).

The $\mathrm{pH}$ was not significantly varied between the two habitats. It was comparatively higher during the post-monsoon season at both the stations. In the seagrass habitat, the $\mathrm{pH}$ varied from 7.47 to 9.02 with the highest mean of $8.86 \pm 0.08$. In the mangrove habitat, it ranged between 7.63 and 8.97 with the highest mean of $8.56 \pm 0.21$. The annual variation was significantly different among stations $(p<0.05)$. In both the ecosystem, comparatively higher alkaline $\mathrm{pH}$ was noticed

Table 1. Annual variations in the mean $( \pm S E, n=12)$ values of the physicochemical parameters of the seagrass and mangrove habitats

\begin{tabular}{|c|c|c|c|c|c|c|}
\hline \multirow{2}{*}{ Parameters } & \multicolumn{2}{|c|}{2013} & \multicolumn{2}{|c|}{2014} & \multicolumn{2}{|c|}{2015} \\
\hline & Seagrass & Mangroves & Seagrass & Mangroves & Seagrass & Mangroves \\
\hline AT $\left({ }^{\circ} \mathrm{C}\right)$ & $30.33 \pm 0.53$ & $31.00 \pm 0.83$ & $30.41 \pm 0.94$ & $30.40 \pm 1.29$ & $30.30 \pm 0.57$ & $31.12 \pm 0.79$ \\
\hline $\operatorname{SST}\left({ }^{\circ} \mathrm{C}\right)$ & $29.51 \pm 0.54$ & $30.23 \pm 0.69$ & $28.82 \pm 0.68$ & $28.56 \pm 1.11$ & $30.13 \pm 0.56$ & $30.11 \pm 0.51$ \\
\hline Salinity (ppt) & $32.33 \pm 0.74$ & $37.87 \pm 1.86$ & $32.80 \pm 1.43$ & $36.08 \pm 2.60$ & $32.51 \pm 0.69$ & $33.72 \pm 2.29$ \\
\hline $\mathrm{pH}$ & $8.38 \pm 0.11$ & $8.38 \pm 0.05$ & $8.25 \pm 0.07$ & $8.19 \pm 0.09$ & $8.00 \pm 0.04$ & $8.01 \pm 0.03$ \\
\hline D.0 (ml.I -1) & $5.12 \pm 0.27$ & $5.39 \pm 0.66$ & $5.70 \pm 0.18$ & $4.10 \pm 0.52$ & $5.03 \pm 0.23$ & $3.49 \pm 0.24$ \\
\hline GPP (mg C L-1 day-1) & $3.78 \pm 2.75$ & $5.04 \pm 1.49$ & $4.74 \pm 2.00$ & $9.80 \pm 3.10$ & $3.93 \pm 1.20$ & $6.36 \pm 1.42$ \\
\hline NPP (mg C L-1 day-1) & $3.24 \pm 2.42$ & $3.95 \pm 1.78$ & $2.39 \pm 1.01$ & $7.62 \pm 3.37$ & $5.40 \pm 2.43$ & $4.71 \pm 1.67$ \\
\hline $\mathrm{NH} 3(\mu \mathrm{g} . \mathrm{I}-1)$ & $0.07 \pm 0.006$ & $0.12 \pm 0.02$ & $0.05 \pm 0.005$ & $0.10 . \pm 0.01$ & $0.02 \pm 0.005$ & $0.05 \pm 0.01$ \\
\hline $\mathrm{TSS}(\mathrm{mg} \mid-1)$ & $363.91 \pm 44.72$ & $380.33 \pm 45.88$ & $283.83 \pm 35.16$ & $461.75 \pm 26.58$ & $399.66 \pm 44.20$ & $529.58 \pm 47.13$ \\
\hline TDS(mg |-1) & $38775 \pm 10862$ & $42900 \pm 10083$ & $38766 \pm 4933$ & $41841 \pm 5183$ & $34933 \pm 4977$ & $37333 \pm 3847$ \\
\hline Chlorophyll-a (mg. m-3) & $1.38 \pm 0.25$ & $8.22 \pm 2.95$ & $0.58 \pm 0.16$ & $3.18 \pm 1.14$ & $0.43 \pm 0.12$ & $1.05 \pm 0.35$ \\
\hline $\mathrm{NO}_{2}(\mu \mathrm{g} . \mathrm{I}-1)$ & $0.34 \pm 0.06$ & $1.51 \pm 0.40$ & $0.44 \pm 0.11$ & $1.96 \pm 0.92$ & $0.50 \pm 0.08$ & $0.91 \pm 0.16$ \\
\hline $\mathrm{NO}_{3}(\mu \mathrm{g} . \mathrm{l}-1)$ & $0.98 \pm 0.64$ & $8.99 \pm 5.88$ & $0.70 \pm 0.65$ & $1.22 \pm 0.95$ & $2.22 \pm 2.08$ & $1.51 \pm 0.88$ \\
\hline $\mathrm{PO}_{4}(\mu \mathrm{g} . \mid-1)$ & $2.62 \pm 0.29$ & $6.77 \pm 3.02$ & $7.92 \pm 1.71$ & $8.67 \pm 2.58$ & $4.15 \pm 1.13$ & $5.66 \pm 0.16$ \\
\hline $\mathrm{SiO}_{3}(\mu \mathrm{g} . \mathrm{I}-1)$ & $17.03 \pm 2.79$ & $41.36 \pm 7.32$ & $3.10 \pm 0.58$ & $9.17 \pm 1.83$ & $1.68 \pm 0.17$ & $3.67 \pm 0.81$ \\
\hline
\end{tabular}


during the post-monsoon season, might be due to the impact of land drainage associated with the northeast monsoon season. The $\mathrm{pH}$ reported in the mangrove habitat of the present study is similar to the observation made by Ajith et al. (2006) in Muthupettai region.

The dissolved oxygen content was comparatively higher in the seagrass habitat and was higher during the post-monsoon season. It varied from $3.69 \mathrm{mlL}^{-1}$ to $6.93 \mathrm{ml} \mathrm{L}^{-1}$ with the highest mean of $5.284 \pm 0.14 \mathrm{mlL}^{-1}$ in the seagrass habitat. In the mangrove habitats, extreme variation was noticed, which ranged between 2.385 and $10.09 \mathrm{mLL}^{-1}$ with a mean of $4.34 \pm 0.3 \mathrm{mlL}^{-1}$. The dissolved oxygen concentration was significantly varied between stations $(p<0.01)$. The value reported in the mangrove habitat in the present study was comparable to the findings of Srilatha et al. (2013) in the Palk Bay area. In both the habitats, the dissolved oxygen was comparatively lower during summer season, which might be due to the higher sea surface temperature. A negative correlation was noticed between dissolved oxygen content and sea surface temperatures $(p<0.05)$, such phenomenon of dropping of dissolved oxygen content during summer season was reported earlier by Sridhar et al. (2008) in Palk Bay.

The Gross Primary Productivity (GPP) and the Net Primary Productivity (NPP) were comparatively higher in the mangrove than the seagrass habitats. In the seagrass habitat, the highest

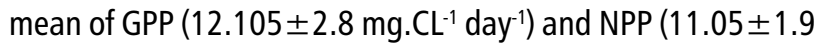
$\mathrm{mgCL}^{-1}$ day $\left.^{-1}\right)$ were reported during the summer season of 2013 . In the mangrove habitat, both GPP and NPP were comparatively higher during the post-monsoon and summer season of 2014 with the highest mean values of $21.07 \pm 5.5 \mathrm{mg} \mathrm{CL}^{-1}$ day ${ }^{-1}$ and $22.94 \pm 8.6 \mathrm{mg} \mathrm{CL}^{-1}$ day ${ }^{-1}$ for GPP and NPP respectively. High positive correlation was also obtained between GPP and NPP $(p<0.01)$. Comparatively a higher primary productivity in mangrove ecosystem reported in the present study, might be due to the higher concentration of nutrients in the seawater. Similar kind of observation was made by Nabeel and Kathiresan (2012) in Pichavaram area.

The chlorophyll-a concentration was average in the seagrass habitat and was comparatively higher in the mangrove habitat. In the seagrass habitat, it ranged from 0 to $2.987 \mathrm{mg}^{-3} \mathrm{~m}^{-3}$ with the highest mean of $1.38 \pm 0.25 \mathrm{mg} \cdot \mathrm{m}^{-3}$ during 2013. In the mangrove beds, the chlorophyll was abnormally higher during the post-monsoon season of 2013 and varied between 0 and $32.67 \mathrm{mg} \cdot \mathrm{m}^{-3}$ The mean value was highest of $8.22 \pm 2.95 \mathrm{mg} \cdot \mathrm{m}^{-3}$ during 2013 (Table 1). The habitat-wise variation in chlorophyll concentration was significant $(p<0.01)$. In the present study, comparatively lesser chlorophyll concentration was observed in the seagrass habitat, when compared to the values noticed by Sulochanan et al. (2011) in Gulf of Mannar and Palk Bay region. The wide fluctuation in the chlorophyll content of the mangrove habitat in the present study was more or less similar to the range reported by Saifullah et al. (2016).

In general, the mangrove habitat recorded comparatively higher total suspended solids (TSS) and total dissolved solids (TDS). Both the station reported higher levels of TSS and TDS during monsoon and post-monsoon season. The TSS was ranged between 82 and $795 \mathrm{mg} \cdot \mathrm{L}^{-1}$ and between 166 and $933 \mathrm{mg} \cdot \mathrm{L}^{-1}$ in the seagrass and mangrove habitats respectively. The mean value was highest of $399 \pm 44.2 \mathrm{mg}^{\mathrm{L}^{-1}}$ in the seagrass habitat and $529.60 \pm 47.13 \mathrm{mg} . \mathrm{L}^{-1}$ in the mangrove habitats. The TDS was varied from 10800 to $149400 \mathrm{mg} . \mathrm{L}-1$ and 14200 to 134200 mg. $\mathrm{L}^{-1}$ for the seagrass and mangrove habitat respectively. The

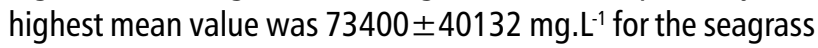
and $78567 \pm 33636 \mathrm{mg} . \mathrm{L}^{-1}$ for the mangrove habitats. The station wise variation in TSS was highly significant $(p<0.001)$. The TSS recorded in the present study in the mangrove waters is in concordance with the range observed in the Sundarban area (Islam et al., 2004) as well with the Palk Bay area (Srilatha et al., 2013). The TSS level in the seagrass habitat of the present study is comparatively higher than the similar observation made in the Gulf of Mannar and Palk Bay (Sulochanan et al., 2011). The higher level of TSS in the Tuticorin coastal waters might be due to the excessive coal transportation for the thermal power plants, and the reclamation activities of the neighbouring Tuticorin Port Trust.

The ammonia concentration was comparatively higher in the mangrove habitat and varied between 0.0008 and $0.098 \mu \mathrm{g} . \mathrm{L}^{-1}$ and 0.012 to $0.352 \mu \mathrm{g} \cdot \mathrm{L}^{-1}$ in the seagrass and the mangrove habitats respectively. The mean value was highest of $0.07 \pm 0.006 \mu \mathrm{g} . \mathrm{L}^{-1} ; 0.12 \pm 0.02 \mu \mathrm{g} . \mathrm{L}^{-1}$ in the seagrass and mangrove habitats, respectively, which was significantly varied between stations $(p<0.01)$. The ammonia concentration reported in the mangrove habitat in the present study was more or less similar to the range reported by Saifullah et al. (2016). The higher value might be probably attributed by the death and subsequent decomposition of inhabited organisms (Segar and Hariharan 1989; Saifullah et al., 2014).

Nutrient concentration (nitrite, nitrate, phosphate and silicate) were also comparatively higher in the mangrove habitats. The nitrite concentration was ranged between $0-1.28 \mu \mathrm{g} \mathrm{L}^{-1}$ with the highest mean of $0.50 \pm 0.08 \mu \mathrm{g} \cdot \mathrm{L}^{-1}$ and between $0-11.6 \mu \mathrm{g} \cdot \mathrm{L}^{-1}$ $\left(1.96 \pm 0.92 \mu \mathrm{g} \cdot \mathrm{L}^{-1}\right)$ for the seagrass and the mangrove habitats, respectively. The mean values of nitrate concentration were highest of $8.37 \pm 1.32 \mu \mathrm{g} . \mathrm{L}^{-1}$ and $8.56 \pm 0.97 \mu \mathrm{g} . \mathrm{L}^{-1}$ for seagrass and mangrove habitats respectively. The phosphate concentration was comparatively higher at both the station during monsoon months and varied from 0.76 to $18.10 \mu \mathrm{g} . \mathrm{L}^{-1}$ and 0.16 to $39.29 \mu \mathrm{g} . \mathrm{L}^{-1}$ for the seagrass and mangrove habitat, respectively. The mean value 
was highest of $8.67 \pm 2.58 \mu \mathrm{g} \cdot \mathrm{L}^{-1}$ for the mangrove habitat. The silicate concentration was abnormally higher during 2013 at both the habitats and ranged from $0.6-36.7 \mu \mathrm{g} \cdot \mathrm{L}^{-1} ; 08-94.1 \mu \mathrm{g} \cdot \mathrm{L}^{-1}$ for the seagrass and mangrove habitats, respectively. In the present study, the comparatively higher concentration of nutrients was noticed in the mangrove habitat. Nabeel and Kathiresan (2012) also noticed such higher values of nutrients in the mangrove beds than the seagrass ecosystem in their studies. The nitrite and silicate concentration were significantly varied between stations $(p<0.01)$. The nitrite and nitrate concentrations recorded in the present study were more or less in the same range of previously reported data in the mangrove waters of India (Pahalawattaarachchi et al., 2009).

In the present study, a higher concentration of phosphate during the monsoon season has been noticed, which is primarily due to the rainfall and associated land runoff. A similar observation of higher phosphate value during the monsoon season has been noticed in Palk Bay also (Kannan and Kannan, 1996; Kathiresan and Masilamani Selvam, 2005; Sridhar et al., 2008; Thangaradjou and Kannan, 2007). In the present study, comparatively a higher concentration of silicate has been noticed in the mangrove habitat. The higher values might be due to the mineralization process. Such higher values of silicate due to the mineralization process have been reported in the Pichavaram mangroves also (Prasad and Ramanathan, 2008).

The annual variation in the sediment quality parameters of both the habitats are depicted in Table 2 . The significant proportion of the sediment in the seagrass habitat was constituted by fine sand, followed by clay, coarse sand and silt. In general, the proportion of fine sand and clay were found to higher during the monsoon season. The fine sand comprised a proportion ranging from $30.7-80.4 \%$ with the highest mean of $66.83 \pm 2.24 \%$; followed by clay with the highest mean of $11.65 \pm 2.5 \%$ (Table 2). The proportion of coarse sand constituted a mean of $8.7 \pm 3.2 \%$ and the least constituted silt comprised by the highest mean of $5.4 \pm 1.3 \%$. The dominance of fine sand followed by silt in the seagrass habitat in the present study is in concordance with the findings of Thangarajdou and Kannan (2007). Similarly, the dominance of clay in the seagrass habitat during the monsoon season in the present study is agreeable to Balakrishnannair et al. (1983). Rajeswari and Kamala (1987) also highlighted that habitats such as sand, mud or sand and mud with thin layers of sand are the most suitable substrates for the seagrass growth. Higher biomass of seagrass at stations with more silt and mud content than the coarse sand was reported in the studies done by Thangarajdou and Kannan (2010).

In the mangrove habitats, though the fine sand constituted the principal constituent, the proportion was comparatively lesser when compared to the seagrass habitat. The fine sand constituted $7.31-79.8 \%$ of the sediment with the highest mean of $41.01 \pm 3.09 \%$. The mean percentage composition of coarse sand was $35 \pm 6.02 \%$. The composition of clay was found to be higher when compared to the seagrass habitat with the highest mean of $15.2 \pm 3.9 \%$. The least represented silt constituted with the highest mean of $5.6 \pm 2.05 \%$. A significant negative correlation was noticed between the fine sand and coarse sand composition of the mangrove habitat $(p<0.05)$. The fine sand and coarse sand were significantly varied between the habitats $(p<0.001)$. The level of significance was higher between the fine sand proportions of post-monsoon and pre-monsoon and between post-monsoon and monsoon $(p<0.01)$. A similar level of higher significant difference was noticed between the coarse sand proportions of post-moon and pre-monsoon and between post-monsoon and summer $(p<0.01)$. Similar to the present findings, very fine-grained sediments was dominant in the mangrove stretch of Gulf of Kutch area (Goutham et al., 2010). The present findings indicated that mangrove plants Avicennia marina can grow in a broad range of bottom substratum.

The percentage of organic matter, organic carbon and total $\mathrm{N}_{2}$ were also comparatively higher in the mangrove sediment. A comparatively higher value of organic carbon was noticed during the pre-monsoon season at both the habitats. The organic carbon was ranged between 0 and $3.4 \% ; 0.03$ and $2.17 \%$ for the seagrass and mangrove habitat, respectively. The mean value

Table 2. Annual variations in the mean $( \pm S E, n=12)$ values of the sediment quality parameters of the seagrass and mangrove habitat

\begin{tabular}{|c|c|c|c|c|c|c|}
\hline \multirow{2}{*}{ Parameters } & \multicolumn{2}{|c|}{2013} & \multicolumn{2}{|c|}{2014} & \multicolumn{2}{|c|}{2015} \\
\hline & Seagrass & Mangroves & Seagrass & Mangroves & Seagrass & Mangroves \\
\hline Clay (\%) & $11.65 \pm 2.52$ & $23.19 \pm 3.29$ & $6.98 \pm 1.78$ & $8.49 \pm 1.81$ & $5.51 \pm 0.70$ & $5.96 \pm 0.85$ \\
\hline Silt (\%) & $5.85 \pm 1.31$ & $7.08 \pm 2.03$ & $3.10 \pm 0.91$ & $2.65 \pm 1.12$ & $4.19 \pm 0.59$ & $5.29 \pm 0.67$ \\
\hline Fine sand(\%) & $66.83 \pm 2.24$ & $25.73 \pm 2.89$ & $54.89 \pm 9.92$ & $38.15 \pm 3.12$ & $52.84 \pm 4.01$ & $41.01 \pm 3.09$ \\
\hline Coarse sand (\%) & $3.34 \pm 1.00$ & $26.02 \pm 5.54$ & $5.12 \pm 1.90$ & $17.39 \pm 1.85$ & $8.88 \pm 1.94$ & $22.23 \pm 2.59$ \\
\hline Org.carbon (\%) & $0.45 \pm 0.26$ & $0.90 \pm 0.14$ & $0.22 \pm 0.03$ & $0.53 \pm 0.08$ & $0.25 \pm 0.05$ & $0.39 \pm 0.06$ \\
\hline Org.matter(\%) & $0.78 \pm 0.46$ & $1.56 \pm 0.24$ & $0.38 \pm 0.06$ & $0.92 \pm 0.13$ & $0.44 \pm 0.08$ & $0.66 \pm 0.11$ \\
\hline Total N2(\%) & $0.03 \pm 0.02$ & $0.07 \pm 0.01$ & $0.01 \pm 0.003$ & $0.04 \pm 0.007$ & $0.02 \pm 0.004$ & $0.03 \pm 0.006$ \\
\hline
\end{tabular}


was highest of $0.83 \pm 0.19 \%$ for the mangrove sediment. Such higher values of organic carbon in the sediment of mangrove habitat might be due to the more significant trapping effect in mangroves. A corresponding increased value of both organic matter and total $\mathrm{N}_{2}$ were also noticed in both the station during the pre-monsoon season. The highest mean of $0.99 \pm 0.61 \%$ and $0.05 \pm 0.03 \% ; 1.4 \pm 0.3 \%$ and $0.07 \pm 0.03 \%$ were reported for organic matter, and nitrogen respectively for the seagrass and mangrove sediments respectively. The organic carbon content in the seagrass sediment in the present study was comparatively lower than that of the reported values from other seagrass habitats of the Gulf of Mannar island ecosystem (Vinithkumar et al., 1999). The lower values might be due to the variations in the sediment texture with lesser retaining capacity of detritus formed (Vinithkumar et al., 1999). The organic carbon content reported from the mangrove sediment in the present study was similar to the range reported in Sundarban area (Islam et al., 2004). A statistically high significant difference was noticed in the variations of these parameters between the two habitats $(p<0.001)$. A high positive correlation was recorded between organic matter, organic carbon and $\mathrm{N}_{2}(p<0.01)$.

According to the PCA result, the two principal components accounted cumulatively for $43.3 \%$ and $48.5 \%$ of the total

Table 3. Eigen values and percentage of explained variability of seagrass \& mangroves habitats

\begin{tabular}{lllllll}
\hline $\mathrm{PC}$ & \multicolumn{2}{c}{ Eigenvalues } & \multicolumn{2}{c}{ \%variation } & \multicolumn{2}{c}{ Cum.\%Vrtn } \\
\hline \multicolumn{2}{c}{ Seagrass } & Mangroves & Seagrass & Mangroves & Seagrass & Mangroves \\
\hline 1 & 3.679 & 4.231 & 17.520 & 20.151 & 17.520 & 20.151 \\
\hline 2 & 2.902 & 3.321 & 13.823 & 15.817 & 31.343 & 35.968 \\
\hline 3 & 2.510 & 2.632 & 11.952 & 12.534 & 43.296 & 48.502 \\
\hline 4 & 1.745 & 1.948 & 8.310 & 9.280 & 51.607 & 57.783 \\
\hline 5 & 1.624 & 1.787 & 7.736 & 8.512 & 59.343 & 66.295 \\
\hline 6 & 1.395 & 1.299 & 6.645 & 6.186 & 65.988 & 72.481 \\
\hline 7 & 1.198 & 1.204 & 5.707 & 5.737 & 71.696 & 78.219 \\
\hline 8 & 1.095 & 1.059 & 5.215 & 5.044 & 76.912 & 83.263 \\
\hline 9 & 0.920 & 0.675 & 4.382 & 3.214 & 81.295 & 86.478 \\
\hline 10 & 0.898 & 0.558 & 4.276 & 2.658 & 85.571 & 89.137 \\
\hline 11 & 0.624 & 0.468 & 2.974 & 2.232 & 88.546 & 91.370 \\
\hline 12 & 0.609 & 0.426 & 2.890 & 2.029 & 91.436 & 93.399 \\
\hline 13 & 0.456 & 0.396 & 2.171 & 1.888 & 93.608 & 95.288 \\
\hline 14 & 0.410 & 0.294 & 1.952 & 1.402 & 95.561 & 96.691 \\
\hline 15 & 0.265 & 0.225 & 1.262 & 1.075 & 96.823 & 97.767 \\
\hline 16 & 0.228 & 0.168 & 1.085 & 0.803 & 97.909 & 98.570 \\
\hline 17 & 0.204 & 0.137 & 0.973 & 0.654 & 98.883 & 99.224 \\
\hline 18 & 0.150 & 0.098 & 0.715 & 0.470 & 99.598 & 99.694 \\
\hline 19 & 0.083 & 0.063 & 0.399 & 0.304 & 99.997 & 99.999 \\
\hline 20 & 0.000 & 0.000 & 0.002 & 0.000 & 99.999 & 99.999 \\
\hline 21 & 0.000 & 0.000 & 0.000 & 0.000 & 100 & 100 \\
\hline
\end{tabular}

variance, for the seagrass and mangrove habitats, respectively (Table 3). In the seagrass habitat, the first principal component PC1 explained $17.5 \%$ of the variability in the data, whereas in mangrove habitat, PC1 explained $20.1 \%$ of the variability in the data. In both the habitats, PC1 had a high contribution from the sediment variables. A strong positive correlation of $0.961,0.962,0.959$ and 0.656 had been reported for sediment variables of seagrass habitat like organic carbon (OC), organic matter (OM), total nitrogen (TN) and total suspended solids (TSS) (Table 4). In the mangrove habitats, the correlation was found to be $0.818,0.820,0.820$ and 0.744 for $\mathrm{OC}, \mathrm{OM}, \mathrm{TN}$ and clay. In the seagrass habitat, the second principal component (PC2) accounted for $13.5 \%$ of the total variance and the parameters like ammonia, silicate, chlorophyll and fine sand were the most influential variables and the $\mathrm{PC} 2$ was inversely linked to nitrite and phosphate. In the mangrove habitat, PC2 accounted for $15.8 \%$ of the total variance and the parameters like dissolved oxygen, NPP, GPP and Chlorophyll were positively correlated and all the sediment variables were negatively correlated (Table 4).

\section{Benthic in-faunal constituents}

The benthic in-faunal biomass was comparatively higher in the seagrass habitats in terms of the density of the constituents. The bivalves were the primary constituent in the seagrass habitat during 2014 and 15, and the second major during 2015 in the mangrove habitat. The bivalves were observed with a mean density of $121.3 \pm 87.6$ and $20.58 \pm 7.24$ nos. $\mathrm{m}^{-2}$ in the seagrass habitat during 2014 and 2015 respectively. In the mangrove habitats, the dominant constituents, the polychaete worms were noticed with a mean density of $30.33 \pm 6.4$ nos. $\mathrm{m}^{-2}$ during 2014 , and the bivalves with the highest density of $24.9 \pm 5.6$ nos. $\mathrm{m}^{-2}$ during 2015. In the seagrass habitat, the second principal constituent, the polychaete worms were seen with the highest mean density of $71.5 \pm 12.3$ nos. $\mathrm{m}^{-2}$ during 2014 , whereas the gastropods were with a mean density of $20.42 \pm 8.28$ nos. $\mathrm{m}^{-2}$ during 2015. The order of dominance of other groups were found as copepod >nematode-worms $>$ isopod $>$ amphipod in the

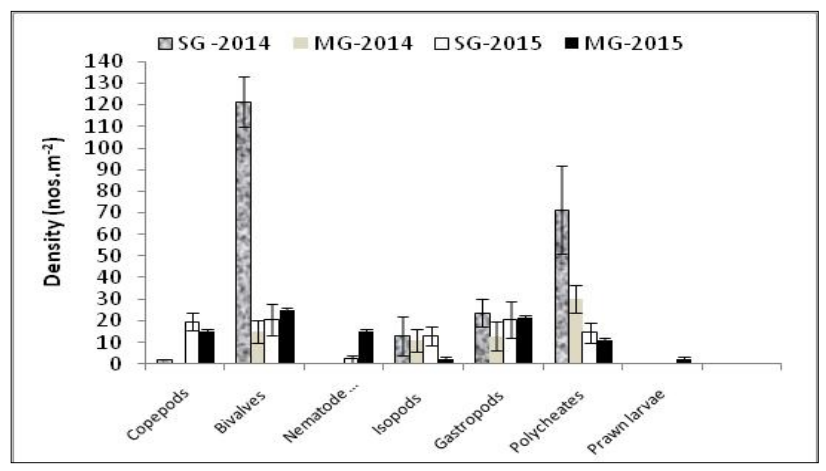

Fig. 1. Mean $( \pm S E, n=18)$ density of benthic in-faunal constituents in the seagrass and mangrove habitats 
Table 4. Correlation based principal component analysis for physico-chemical variables

\begin{tabular}{|c|c|c|c|c|c|c|c|c|}
\hline \multirow{2}{*}{ Variables } & \multicolumn{2}{|c|}{ PC1 } & \multicolumn{2}{|c|}{ PC2 } & \multicolumn{2}{|c|}{ PC3 } & \multicolumn{2}{|c|}{ PC4 } \\
\hline & Seagrass & Mangroves & Seagrass & Mangroves & Seagrass & Mangroves & Seagrass & Mangroves \\
\hline SST & -0.017 & 0.078 & -0.044 & 0.135 & 0.405 & 0.364 & 0.591 & 0.714 \\
\hline Salinity & -0.148 & 0.253 & -0.081 & -0.151 & 0.168 & 0.201 & 0.223 & 0.386 \\
\hline $\mathrm{pH}$ & 0.161 & 0.567 & 0.614 & 0.198 & 0.407 & -0.036 & 0.149 & -0.108 \\
\hline DO & -0.100 & 0.346 & -0.051 & 0.525 & -0.657 & 0.208 & -0.041 & 0.305 \\
\hline GPP & -0.114 & -0.093 & -0.112 & 0.501 & 0.500 & 0.642 & -0.481 & -0.283 \\
\hline NPP & -0.195 & -0.059 & -0.153 & 0.523 & 0.592 & 0.607 & -0.239 & -0.494 \\
\hline Chlorophyll & -0.143 & 0.309 & 0.662 & 0.627 & 0.280 & -0.115 & 0.114 & 0.028 \\
\hline TSS & 0.656 & -0.481 & -0.175 & -0.311 & 0.039 & 0.148 & 0.308 & 0.354 \\
\hline TDS & -0.166 & 0.078 & -0.045 & 0.187 & -0.693 & -0.430 & 0.002 & -0.143 \\
\hline $\mathrm{NH}_{3}$ & 0.014 & 0.225 & 0.766 & 0.136 & -0.148 & 0.189 & 0.057 & 0.556 \\
\hline $\mathrm{NO}_{2}$ & -0.316 & 0.119 & -0.385 & 0.262 & -0.278 & 0.741 & -0.194 & -0.287 \\
\hline $\mathrm{PO}_{4}$ & -0.233 & 0.015 & -0.250 & -0.162 & -0.022 & 0.503 & -0.287 & 0.015 \\
\hline $\mathrm{SiO}_{2}$ & 0.182 & 0.645 & 0.724 & 0.364 & 0.040 & -0.240 & -0.201 & 0.186 \\
\hline $\mathrm{NO}_{3}$ & -0.073 & 0.186 & 0.075 & 0.232 & 0.068 & 0.058 & -0.051 & 0.312 \\
\hline Clay & -0.018 & 0.743 & 0.337 & 0.126 & -0.510 & -0.189 & 0.443 & -0.277 \\
\hline Silt & -0.287 & 0.390 & 0.265 & -0.279 & 0.194 & -0.368 & -0.364 & -0.303 \\
\hline FS & 0.159 & -0.366 & 0.575 & -0.684 & -0.194 & 0.263 & -0.159 & -0.100 \\
\hline CS & -0.144 & 0.043 & -0.346 & 0.627 & 0.337 & -0.376 & 0.597 & 0.076 \\
\hline$O C$ & 0.960 & 0.818 & -0.117 & -0.469 & 0.001 & 0.204 & -0.120 & -0.027 \\
\hline$\overline{\mathrm{OM}}$ & 0.960 & 0.820 & -0.114 & -0.466 & 0.000 & 0.206 & -0.120 & -0.029 \\
\hline T.N2 & 0.959 & 0.820 & -0.116 & -0.466 & 0.002 & 0.208 & -0.126 & -0.025 \\
\hline
\end{tabular}

seagrass beds and nematode worms $>$ isopod $>$ copepod $>$ prawn larvae $>$ amphipod in the mangrove habitats (Fig.1). The presence of chaetognath was seen only in the seagrass beds and prawn larvae only in the mangrove beds. The number of taxa and the density of in-faunal constituents in the seagrass habitat were comparatively lesser when compared to the studies of Liao et al. (2015) in Taiwan waters. The dominance of bivalve followed by polychaete worms in the seagrass ecosystem might be due to the comparatively higher clay fraction of the sediment. A high positive correlation was noticed between clay and the density of bivalves and polychaete worms in the seagrass habitats $(p<0.05)$.

Similarly, a high positive correlation was noticed between fine sand and gastropod density of mangrove ecosystem $(p<0.05)$. Giere (1993) indicated that the distribution of benthic infaunal constituents is closely linked to the sediment structure and chemistry. The variation in in-faunal constituents in the seagrass habitats observed is agreeable to the spatial and temporal variations noticed by Boye et al. (2017) in the North Sea and the Bay of Biscay. Sediment conditions and the forces that shape them are often the main factors structuring the infaunal communities (Gray, 1974). The dominance of polychaete worms in the mangrove habitat in the present study agrees with the findings of Dittmann (2001) in Australian waters. The abundance of benthic in-faunal constituents recorded in the mangrove sediments was lower when compared to similar studies (Alongi and Christoffersen, 1992). The lower abundance of in-faunal constituents in the mangrove sediments in the present study might be due to the high saline condition of the habitat causing poor quality of available food. Moreover, the sandy nature of the bottom substratum also influences the in-faunal load, as most of them prefer muddy substratum as indicated by Dissanayake and Chandrasekara, (2014). Therefore, a detailed study of sediment quality parameters to address the ecology and distribution of benthic fauna is recommended for these habitats.

\section{Sea grass productivity}

In the seagrass habitats, the seagrass population was constituted mainly by two species Halodule uninervis and Halophila ovalis during the period 2013-2014 and four species like Halodule uninervis, Halophila ovalis, Syringodium isoetifolium and Cymodocea serrulata during 2015. The mean values of the annual variation in the biomass of seagrass species are indicated in Fig. 2. Halodule unnervis was the dominant species during 2013-2014 with the above-ground biomass ranging from 92 


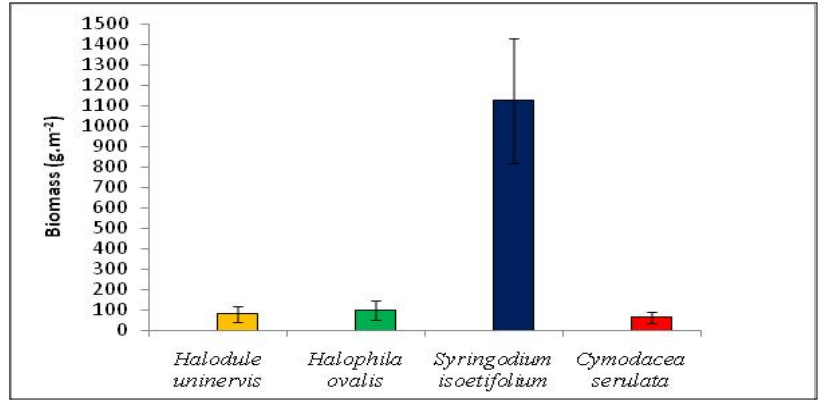

Fig. 2. Mean ( $\pm S E ., n=36)$ biomass of seagrass species in the habitat

to $960 \mathrm{~g} \cdot \mathrm{m}^{-2}$ with the highest mean of $451 \pm 72.8 \mathrm{~g} \cdot \mathrm{m}^{-2}$ during 2014. A high positive correlation was seen in the above-ground biomass of Halodule uninervis and Halophila ovalis $(p<0.05)$. Halophila ovalis; the other dominant species reported with the highest mean above-ground biomass of $375.8 \pm 53.8 \mathrm{~g} \cdot \mathrm{m}^{-2}$ during 2014. During the year 2015, Syringodium isoetifolium was the most dominant species and was prevalent throughout the year and seen at the highest above-ground biomass of $3210 \mathrm{~g} \cdot \mathrm{m}^{-2}$ during December and the mean biomass was highest of $1127 \pm 305.98 \mathrm{~g} \cdot \mathrm{m}^{-2}$. Halophila ovalis, the second significant species was with the mean biomass of $98.83 \pm 46.45 \mathrm{~g} \cdot \mathrm{m}^{-2}$. Halodule uninervis $(80.83 \pm 37.83 \mathrm{~g} . \mathrm{m}-2)$ and Cymodocea serrulata $\left(63.3 \pm 26.32 \mathrm{~g} \cdot \mathrm{m}^{-2}\right)$ were also represented the seagrass communities as the third and fourth dominant species. In the present studies, the highest above-ground biomass of seagrass species was reported during the monsoon season, which is in concordance with the findings of Thangarajdou and Kannan, (2010). The biomass obtained for various seagrass species were found to be lesser when compared to studies conducted on similar aspects, which might be due to the lesser silt and clay content of the bottom soil as indicated as the prerequisite for the seagrass by Estacion and Fortes (1988).

The present study highlighted the present health status of both the seagrass and mangrove habitats of Tuticorin coast in terms of the physicochemical parameters of the water, sediment and the benthic in-faunal community structure. The studies proved that the mangrove habitat is profoundly impacted when compared to the seagrass habitat, mainly due to the influence of high saline water from neighbouring salt pans. Many abnormal water and sediment quality parameters like higher GPP, NPP, salinity, chlorophyll-a, TDS, TSS, ammonia, nitrite, nitrate and silicate in water, higher organic carbon, organic matter and $\mathrm{N}_{2}$ in the sediment were reported from the mangrove habitats. The seagrass habitat is impacted mainly by the reclamation and the transportation activities of the neighbouring port. Higher values of total suspended solids and dissolved solids in the water and high content of fine sand in the sediment are indicative of this. The lower density and less diverse benthic in-faunal community structure also indicated the harshness of the sediments of both the habitats. Considering the role played by these habitats, as an ultimate refuge for climate change issues, the present study also warrants the need for the effective management strategies for conserving and sustainable utilisation of these resources in Tuticorin coastal waters.

\section{Acknowledgements}

The authors are thankful to the funding support of the Indian Council of Agricultural Research, Government of India. The encouragement and the facilities provided by the Director, ICAR-CMFRI, Kochi and the Scientist-in-Charge, Tuticorin Research Centre of ICAR-CMFRI, to carry out this work are also significantly acknowledged.

\section{References}

Abal, E. G. and W. C. Dennison. 1996. Seagrass depth range and water quality in Southern Moreton Bay, Queensland, Australia. Mar. Freshwater. Res., 47: 763-771.

Ajith kumar, T. T., T. Thangaradjou and L. Kannan. 2006. Physico-chemical and biological properties of the Muthupettai mangroves in Tamil Nadu. J. Mar. Biol. Ass. India, 48: 131-138.

Alboukadel, K. and F. Mundt. 2017. factoextra: Extract and Visualize the Results of Multivariate Data Analyses. R package version 1.0.5. https://CRAN.R-project.org/ package $=$ factoextra .

Alongi, D. M. and P. Christoffersen. 1992. Benthic infauna and organism-sediment relations in a shallow, tropical coastal area: influence of outwelled mangrove detritus and physical disturbance Benthic infauna and organism-sediment relations in a shallow, tropical coastal area: influence of outwelled mangrove detritus and physical disturbance. Mar. Ecol. Prog. Ser, 81: 229-24

Anilakumari, K. S. 2016. Distribution of Meiofauna in the Poonthura Estuary, Thiruvananthapuram, Kerala. Int. J. Pure App. Biosci., 4: 121-126.

Asha, P. S. and K. Diwakar. 2007. Hydrobiology of the inshore waters off Tuticorin in the Gulf of Mannar. J. Mar. Biol. Ass. India, 49: 7-11.

Balakrishnannair, N., M. Arunachalam., P. K. Abdul Azis., K. Dharmaraj and K. Krishna Kumar. 1983. Ecology of Indian estuaries. Part II-Ecology of seagrass beds of Halophila ovalis (Hook) in the Ashtamudi estuary, south west coast of India. Indian J. Mar. Sci., 12: 151-153.

Boye, A., P. Legendr., J. Gralla and O. Gauthier. 2017. Constancy despite variability: Local and regional macrofaunal diversity in intertidal seagrass beds. J. Sea Res, 130:107-122.

Dennison, W. C. and H. Kirkman. 1966. Seagrass survival model. In: J. Kuo, R. C. Phillips, D. I. Walker and K. Kirkman (Eds.), Proceedings of an International Workshop on Seagrass Biology, Rottnest Island, Western Australia. p. 341-344.

Dissanayake, N. and U. Chandrasekara, 2014. Effects of Mangrove Zonation and the Physicochemical Parameters of Soil on the Distribution of Macrobenthic Fauna in Kadolkele Mangrove Forest, a Tropical Mangrove Forest in Sri Lanka. Advances in Ecology, Article ID 564056, 2014: 13 pp

Dittmann, S. 2001. Abundance and distribution of small infauna in mangroves of Missionary Bay, North Queensland. Australia Rev. Biol. Trop., 49: 535-544.

Estacion, J. S. and A. D. Fortes. 1988. Growth rates and primary production of Enhalus acoroides (L.f) Royle from Lag-it, North Basis, Bay, Phillippines. Aquat. Bot., 29:347-356

Giere, O. 1993. Meiobenthology: the microscopic fauna in aquatic sediments. SpringerVerlag, Berlin. 328 pp.

Goutham, K., A. L. Ramanathan and K. Rajkumar. 2010. Textural characteristics of the surface sediments of a Tropical mangrove ecosystem, Gulf of Kachch, Gujarat, India. Indian J. Mar. Sci., 39: 415-422.

Grasshoff, K. 1983. Determination of salinity. In Methods of Seawater Analysis. K. Grasshoff, M. Elxhardt and K. Kremling, Eds, Wiley-WCH, Weinheim, Wiley- VCH, Weinheim. 31 pp.

Grasshoff, K., K. Kremling and M. Ehrhardt. 1999. Methods of Seawater Analysis. Wiley- VCH, Weinheim, 3rd ed., 634 pp.

Gray, J. S. 1974. Animal-sediment relationships. Oceanogr. Mar. Biol. Annl. Rev, 12: 223-261.

Holme, N. A. and A. D. Mc Intyre. 1971. Methods for the study of marine benthos. IBP hand book No.16 Blackwell scientific publications, 334 pp. 
Islam, M. L., M. J. Alam., S. Rheman., S. O. Ahmed and M. A. Mazid. 2004. Water quality, nutrient dynamics and sediment profile in shrimp farming of the Sunderbans mangrove forest, Bangladesh. Indian J. Mar. Sci., 33: 170-176.

Jayanthi, M., P. Ravichandran and A. G. Ponniah. 2010. Status of mangroves in relation to brackishwater aquaculture development in Tamil Nadu, India, Central Institute of Brackish water Aquaculture, Bulletin.21. p. 1- 35.

Kamalkanth, S., M. M. Muniyan and A. Christyponni. 2012. "Seasonal variations in physico- chemical parameters at Tranquebar, coastal Nagapattinam, Tamil Nadu, India". Int. J. Environ. Sci., 2: 203-207.

Kannan, R. and L. Kannan. 1996. Physico-chemical characteristics of seaweed beds of Palk Bay, southeast coast of India. Indian J. Mar. Sci., 256: 358-362.

Kathiresan, K. 2000. A review of studies on Pichavaram mangrove, southeast India. Hydrobiolgia, 430:185-205.

Kathiresan, K. and M. Masilamani Selvam. 2005. Evaluation of beneficial bacteria from mangrove soil. Bot. Mar., 49:86-88.

Moore, K. A., A. Hilary., H. A. Neckles and R. J. Orth. 1996. Zostera marina (eelgrass) growth and survival along a gradient of nutrients and turbidity in the lower Chesapeake Bay Zostera marina (eelgrass) growth and survival along a gradient of nutrients and turbidity in the lower Chesapeake Bay. Mar. Ecol. Prog. Ser., 142: 247-259.

Lewis, D. W. 1984. Practical Sedimentology. Hutchinson Ross Publishing Company. $229 \mathrm{pp}$.

Liao, J. X., H. M. Yeh and H. K. Mok. 2015. Meiofaunal communities in a tropical seagrass bed and adjacent unvegetated sediments with note on sufficient sample size for determining local diversity indices. Zool. Stud., 54:14.

Nabeel, M. A. and K. Kathiresan. 2012. Phytoplankton productivity in interlinked mangroves, seagrass and coral reefs and its ecotones in Gulf of Mannar Biosphere Reserve, South east India, Mar. Biol. Res., 8: 61-73.

Rajeswari, M. and G. Kamala. 1987. Ecological conservation of seagrass beds in the Gulf of Mannar, India. Environ. Conserv., 14: 265-268.

Pahalawattaarachchi, V., C. S. Purushothaman and A. Vennila. 2009. Metal phytoremediation potential of Rhizophora mucronata (Lam.). Indian J. Mar. Sci., 38: 178-183.

Parson, T., Y. Maita and C. A. Lalli. 1984. Manual of chemical and biological methods for seawater analysis. Pergamon, New York, 184 pp.

Prabhakaran, M. P. S. Bijoy Nandan., P. R. Jayachandran and N.G.K. Pillai. 2013. Species diversity and community structure of ichthyofauna in the seagrass ecosystem of Minicoy Atoll, Lakshadweep India. Indian J. Mar. Sci., 42: 349-359.

Prasad, B. K. M. and A. L. Ramanathan. 2008. Dissolved organic nutrients in the Pichavaram mangrove waters of east coast of India. Indian J. Mar. Sci., 37: 141-145.
R Core Team. 2019. R: A language and environment for statistical computing. R Foundation for StatisticalComputing,Vienna, Austria. URL https://www.R-project.org/.

Saifullah, A. S. M., M. K. Abu Hena, M. H. Idris and A. R. Halimah. 2014. "Seasonal Variation of Water Characteristics in Kuala Sibuti River Estuary in Miri, Sarawak, Malaysia." Malaysian J. Sci., 33: 9-12.

Saifullah, A. S. M., M. K. Abu Hena, M. H. Idris, R. Amy Halimah, M. K. Bhuiyan and M. N. Hoque. 2016. Inter- -chemical and biological factors in the tropical mangrove estuary. Zool. Ecol., p. 141-149.

Sebastien Le., J. Josse and F. Husson. 2008. FactoMineR: An R Package for Multivariate Analysis. J. Stat. Softw., 25: 1-18.

Segar, K. and V. Hariharan. 1989. Seasonal distribution of nitrate, nitrite, ammonia and plankton in effluent discharge area off Mangalore, West coast of India. Indian J. Mar. Sci, 18: 170-173.

Solarzano, L. 1969. Determination of ammonia in natural waters by the phenol hypochlorite method. Limnol. Oceanogr., 14: 799 - 801

Sridhar, R., T. Thangaradjou and L. Kannan. 2008. Comparative investigation on physico-chemical properties of the coral reef and seagrass ecosystem of the Palk Bay. Indian. J. Mar. Sci., 37: 207-213.

Srilatha, G., D. Varadharajan, K. Chamundeeswari and P. Mayavu. 2013. Study on Physico-Chemical Parameters in Different Mangrove Regions, Southeast Coast of India. J. Anal. Toxicol., 3: 5

Sulochanan, B., A. K. Kumaraguru and L. S. Korabu. 2011. Hydrological conditions in seagrass beds in Palk Bay and Gulf of Mannar, southeast coast of India. J. Mar. Biol. Ass. India, 53: $108-115$.

Tewari, A., H. V. Joshi., C. Raghunathan., H. Trivedi and P. K. Ghosh. 2003. The effect of seabrine and bittern on survival and growth of mangrove Avicennia marina (Dicotyledones: Avicenniaceae). Indian J. Mar. Sci., 32: 52-56.

Thangaradjou, T. and L. Kannan. 2007. Nutrient characteristics and sediment texture of the seagrass beds of the Gulf of Mannar. J. Environ. Biol., 28: 29-33.

Thangaradjou, T. and L. Kannan. 2010. Productivity and Biomass of seagrasses of the Gulf of Mannar Biosphere Reserve. J. Sci. Trans. Environ. Technol., 4: 27-36.

Vinithkumar, N. V., S. Kumeresan., M. Manjusha and T. Balasubramanian.1999. Organic matter, nutrients and major ions in the sediments of coral reefs and seagrass beds of Gulf of Mannar biosphere reserve, southeast coast of India. Indian J. Mar. Sci., 28: $383-393$.

Walkley, A. and T. A. Black. 1934. An experimentation of the vegetative method for determining organic matter and proposed modification of chromic acid titration method. Soil Sci., 37: 29-38.

Winkler, L. W. 1888. Die Bestimmung des in Wassergelosten Sauerstoffen. Berichte der Deutschen Chemischen Gesellschaft, 21: 2843-2855. 